Jurnal Ners Volume 4 Nomor 1 Tahun 2020 Halaman 59-67

JURNAL NERS

Research \& Learning in Nursing Science

http://journal.universitaspahlawan.ac.id/index.php/ners

\title{
KUALITAS PELAYANAN PUBLIK DI KANTOR UTD PMI KOTA PEKANBARU
}

\author{
Sudaryanto \\ Program Studi Administrasi Negara \\ Universitas Lancang Kuning \\ Yoyoksudaryanto351@gmail.com
}

\begin{abstract}
Abstrak
Kegiatan donor darah secara khusus menjadi tanggung jawab Unit Tranfusi Darah Palang Merah Indonesia Kota Pekanbaru. Selain itu juga ada yang menjadi kewenangan rumah sakit dengan membentuk Bank Darah dan untuk hal tertentu penanganan khusus menjadi kewenangan pemerintah pusat. Mengingat pentingnya darah bagi misi kemanusiaan maka diperlukan keterlibatan aktif seluruh elemen masyarakat untuk mendonorkan darahnya secara rutin. Dari observasi yang dilakukan ditemukan permasalahan masih ditemukan masyarakat yang kebingungan dalam pengurusan administrasi. Kemudian masih banyak warga Kota Pekanbaru yang belum pernah melakukan kegiatan donor darah, belum semua instansi yang mewajibkan pegawainya untuk melakukan donor darah. Oleh karena itu perlu dilakukan penelitian kualitatif guna mengatasi permasalahan tersebut menggunakan teori Lijan Sipoltak. Informan yang digunakan adalah aparatur unit donor darah dan masyarakat. Hasilnya, kualitas pelayanan publik sudah berjalan sesuai ketentuan yang berlaku namun masih perlu peningkatan.
\end{abstract}

Kata Kunci: Kualitas, Pelayanan dan Publik

\begin{abstract}
Blood donor activities are specifically the responsibility of the Indonesian Red Cross Blood Transfusion Unit Pekanbaru City. In addition, there is also the authority of the hospital to form a Blood Bank and for certain cases special handling becomes the authority of the central government. Given the importance of blood for humanitarian missions, it is necessary to have the active involvement of all elements of society to donate blood regularly. From the observations made, it was found that problems were still found by people who were confused in administrative matters. Then there are still many Pekanbaru City residents who have never done blood donor activities, not all agencies that require employees to do blood donations. Therefore it is necessary to do qualitative research to overcome these problems using the Lijan Sipoltak theory. The informants used were blood donor and community apparatus units. As a result, the quality of public services has run according to applicable regulations but still needs improvement.
\end{abstract}

Keywords: Quality, Service and Public

@ Jurnal Ners Prodi Sarjana Keperawatan \& Profesi Ners FIK UP 2020

$\triangle$ Corresponding author :

Address : Jl. Tuanku Tambusai No. 23 Bangkinang

Email : Yoyoksudaryanto351@gmail.com

Phone : 085265987253 


\section{PENDAHULUAN}

Setiap warga Negara Indonesia wajib menjalankan Pancasila sebagai ideologi Negara tanpa terkecuali. Begitu pula dengan implementasi dari pengamalan sila tersebut termasuk Sila Kedua, Kemanusiaan Yang Adil Dan Beradab. Perwujudan sila ini dapat dilakukan dalam berbagai bentuk, salah satunya keterlibatan warga Negara dalam kegiatan donor darah. Kegiatan donor darah secara pribadi memberikan dampak positif bagi kesehatan sedangkan dari segi sosial memberikan bantuan kemanusiaan.

Kegiata donor darah secara khusus menjadi tanggung jawab Unit Tranfusi Darah Palang Merah Indonesia (UTD PMI) Kota Pekanbaru. Selain itu juga ada yang menjadi kewenangan rumah sakit dengan membentuk Bank Darah dan untuk hal perlu penanganan khusus menjadi kewenangan pemerintah pusat. Mengingat pentingnya darah bagi misi kemanusiaan maka diperlukan keterlibatan aktif seluruh elemen masyarakat untuk mendonorkan darahnya secara rutin.

Hal ini dilakukan UTD PMI Kota Pekanbaru menjalin kerjasama dengan berbagai pihak seperti pemerintah, perguruan tinggi dan perusahaan serta individu-individu masyarakat. Hasilnya cukup memuaskan meskipun tetap terjadi kekurangan. Artinya, ada peningkatan kebutuhan stok darah namun masih belum bisa memenuhi kebutuhan dikarenakan masih terjadi kekurangan stok darah.

Oleh karena itu UTD PMI Kota Pekanbaru perlu meningkatkan kualitas pelayanan public sehingga mampu memenuhi kebutuhan dan kepuasan masyarakat. Dari informasi yang diperoleh belum semua perguruan tinggi yang menjalin kerjasama dengan UTD PMI Kota Pekanbaru untuk melakukan kegiatan donor darah. Begitu pula dengan perusahaan-perusahaan yang ada tidak semuanya mewajibkan karyawan untuk melakukan donor darah. Pemerintah (daerah) sendiri baru menjadikan kegiatan donor darah sebagai acara simbolis tahunan. Melihat kondisi tersebut maka besar potensi yang bisa dibangun untuk memberdayakan atau melibatkan masyarakat untuk aktif melakukan kegiatan donor darah.

Bahkan masyarakat secara pribadi sudah ada yang bersedia mendonorkan darah. Namun ada kategori aktif dan pasif. Aktif, mereka melakukannya dalam kurun waktu dua bulan sekali. Pasif, masyarakat yang hanya memberikan darah ketika dibutuhkan saja. Dari observasi yang dilakukan ditemukan permasalahan sebagai berikut;

- Masih ditemukan masyarakat yang kebingungan dalam pengurusan administrasi.

- Masih banyak warga Kota Pekanbaru khususnya yang belum pernah melakukan kegiatan donor darah.

- Belum semua instansi pemerintah dan swasta yang mewajibkan pegawai/ karyawannya untuk melakukan donor darah.

Konsep administrasi dapat diartikan sebagai suatu proses pengorganisasian tugastugas dan kegiatan dari berbagai tingkatan dan jenis pekerjaan secara sistematik dalam organisasi. Proses administrasi secara hierarki mengerjakan tiga fungsi utama, yaitu (1) fungsi pengarahan organisasi yang berkaitan dengan proses perencanaan jangka panjang, (2) fungsi manajemen organisasi yang berkaitan dengan upaya mempertahankan organisasi sebagai suatu pekerjaan yang terus berlangsung lama, seperti memberikan bahan, sarana, instruksi dan peciptaan iklim yang diperlukan oleh staf teknis atau professional yang terlibat dalam proses produksi, (3) fungsi pengawas, yaitu kontroling dan evaluasi atasan kepada bawahan dengan cermat, tegas dan dapat dipertangungjawabkan dengan baik dan benar, (Asep, 2012).

Menurut Zeithhaml - Parasurman Berry dalam Harbani Pasolong (2011), untuk mengetahui kualitas pelayanan yang dirasakan secara nyata ditentukan oleh lima indicator, yakni: 
1. Tangibles: kualitas pelayanan berupa sarana fisik perkantoran, komputerisasi administrasi, ruang tunggu, tempat informasi.

2. Realibility: kemampuan dan keandalan untuk menyediakan pelayanan yang terpercaya.

3. Responsivess: kesanggupan untuk membantu dan menyediakan pelayanan secara cepat dan tepat serta tanggap terhadap keinginan konsumen.

4. Assurance: kemampuan dan keramahan serta sopan santun pegawai dalam meyakinkan kepercayaan konsumen.

5. Emphaty: sikap tegas tetapi penuh perhatian dari pegawai terhadap konsumen.

Secara teoritis tujuan pelayanan publik pada dasarnya adalah memuaskan masyarakat. Untuk mencapai kepuasan itu menurut Lijan Sipoltak, dituntut kualitas pelayanan prima yang tercermin dari: transparansi, akuntabilitas, kondisional, partisipatif, kesamaan hak dan keseimbangan hak dan kewajiban.

\section{METODE PENELITIAN}

\section{Lokasi Dan Waktu Penelitian}

Penelitian dilakukan di Kantor Unit Transfusi Darah Palang Merah Indonesia (UTD PMI) Kota Pekanbaru. Penelitian dilaksanakan bulan Januari-Mei 2020.

\section{Informan/ Narasumber}

Informan ataupun narasumber dalam penelitian ini adalah Aparatur UTD PMI Kota Pekanbaru dan masyarakat.

\section{Sumber dan Jenis Data}

Sumber dan jenis data dalam penelitian ini adalah sebagai berikut:

\section{Data Primer}

Data Primer adalah data yang kumpulkan langsung dari informan yang terpilih dalam penelitian ini. Dalam kegiatan penelitian kualitatif yang menjadi Aparatur pemerintah informasi adalah para informan (subjek) yang kompeten, mempunyai relevansi dengan setting sosial yang diteliti. Sedangkan tempat yang menjadi elemen dari situasi sosial adalah situasi dan kondisi lingkungan tempat yang berkaitan dengan permasalahan penelitian. (Iskandar, 2009:113).

\section{Data Sekunder}

Data sekunder adalah data yang diperoleh dari literatur-literatur, media cetak, atupun media elektronik, dokumen administrasi, penelitian sebelum atau lainnya yang terkait.

\section{Teknik Pengumpulan Data}

Untuk menghimpun data yang diperlukan, maka dipergunakan teknik pengumpulan data dengan cara observasi, wawancara dan dokumentasi. Peneliti mengobservasi atau melihat apa yang sedang berlangsung dilapangan, dalam hal ini peneliti mengunjungi lokasi atau melihat secara langsung proses keberlangsungan kegiatan perkantoran. Wawancara adalah proses tanyajawab dalam penelitian yang berlangsung secara lisan dalam mana dua orang atau lebih bertatap muka mendengarkan secara langsung informasi-informasi atau keteranganketerangan. (Narbuko, 2008: 83). Data - daa terkait dengan kegiatan penelitian baik dalam bentuk photo maupun keterangan tertulis lainnya.

\section{Analisis Data}

Data yang telah terkumpul selanjutnya dianalisis secara deskriptif kualitatif. Analisis data dilakukan secara deskriptif kualitatif, dimana peneliti mencari makna, pemahaman, pengertian tentang suatu fenomena, kejadian maupun kehidupan manusia dengan terlibat langsung dan atau tidak langsung dalam setting yang diteliti, konstekstual dan menyeluruh.

Selanjutnya pengujian data dengan uji kredibilitas antara lain melakukan triangulasi sesuai aturan (mencari sumber yang lebih banyak). Analisis data dilakukan sebelum ke 
lapangan dan selama dilapangan (menggunakan model Miles dan Huberman yakni reduksi data/ pemilihan/ penghimpunan/ data mentah, display/ pengumpulan informasi dan kesimpulan/ verifikasi).

\section{HASIL DAN PEMBAHASAN HASIL}

Dari penelitian yang dilakukan diketahui bahwa kualitas pelayanan di Kantor Unit Tranfusi Darah Palang Merah Indonesia (UTD PMI) Kota Pekanbaru sudah berjalan dengan standar yang telah ditetapkan. Hal ini dibuktikan dengan usaha yang dilakukan untuk menjaga kualitas dan kesinambungan pelayanan Kantor UTD PMI Kota Pekanbaru senantiasa selalu melakukan evaluasi setiap minggu melalui rapat evaluasi.

Seiring dengan peningkatan kebutuhan darah di Provinsi Riau khususnya di Kota Pekanbaru Kantor UTD PMI Kota Pekanbaru dihadapkan pada tuntutan pelayanan darah yang memiliki standar pelayanan keamanan yang semakin tinggi baik peralatan maupun teknologi. Hal ini untuk mengantisipasi/ mencegah terjadinya penularan penyakit mematikan yang dikenal Infeksi Menular Lewat Tranfusi Darah (IMLTD). Kantor UTD PMI Kota Pekanbaru telah menjadi salah satu unit donor darah (UDD) yang mendapat bantuan peralatan Nucleid Acid Test (NAT) dari Kementerian Kesehatan Republik Indonesia. NAT ini merupakan salah satu alat pendeteksi tercanggih penyakit menular.

Kantor UTD PMI Kota Pekanbaru juga memiliki alat apheresis yang sangat bermanfaat dalam proses pengambilan darah sesuai kebutuhan pasien. Dengan kondisi tersebut menambah kepercayaan masyarakat terhadap kualitas pelayanan yang diberikan.

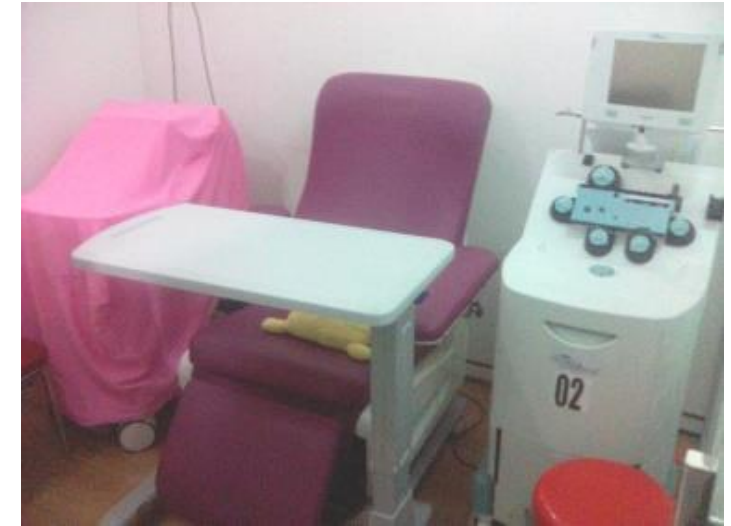

Gambar 1. Mesin Apheresis

Kecanggihan teknologi dan peralatan yang diberikan tentunya secara langsung mampu meningkatkan kepercayaan masyarakat terhadap UTD PMI Kota Pekanbaru. Apalagi UTD PMI Kota Pekanbaru merupakan salah satu dari UDD Tipe A yang ada di Indonesia. UTD ini selain menjalankan fungsi sebagai fasilitas pelayanan darah juga berfungsi sebagai rujukan dan pembina seluruh UDD yangada di Provinsi Riau. Untuk mencapai kualifikasi Tipe A harus mampu memenuhi persyaratan manajemen, sumber daya manusia, dan peralatan yang berkualitas sesuai dengan standar Kementerian Kesehatan RI. Berbagai peningkatan sarana prasarana serta pembenahan yang dilakukan secara berkesinambungan merupakan upaya internal guna memperbaiki kaulitas layanan.

\section{PEMBAHASAN \\ Transparansi}

Segala pelayan yang dilakukan di Kantor UTD PMI Kota Pekanbaru dilakukan secara transparan dari awal hingga akhir; dari prosedur awal permintaan darah hingga penyerahannya kepada keluarga pasien. Semua pihak dapat melakukannya secara online dan offline. Menurut Lijan Poltak, transparansi yakni pelayanan yang bersifat terbuka, mudah dan dapat diakses oleh semua pihak yang membutuhkan dan disediakan secara memadai serta mudah dimengerti.

Hal ini diwujudkan di Kantor UTD PMI Kota Pekanbaru dengan pelayanan yang 
terbuka untuk siapa, tidak ada pembatasan. Baik itu persyaratan prosedur pelayanan permintaan darah, dan pembiayaan, kecuali proses pengolahan karena memang perlu ruangan khusus dan tidak semua orang bisa masuk kecuali petugas guna menjaga sterillisasi.

Pelayanan yang diberikan mudah karena cukup dengan membawa surat/ blangko permintaan darah yang telah diiisi lengkap dan ditanda tangani. Menurut Kepala Sub Bagian Kepgawaian Dan Sistem Informasi Manajemen, Satrio Dewa, tarif biaya pengolahan darah Rp 360.000 berlaku untuk siapa saja tanpa pengecualian disesuaikan dengan jaminan kesehatan yang dipakai. Ada yang gratis karena sebenarnya ditanggung oleh kantor atau penyelenggaran jaminan kesehatan.

Namun standar biaya ini tidak tertulis di papan pengumuman atau lainnya sehingga masyarakat masih harus kembali bertanya tentang fasilitas kesehatan yang mereka dapatkan. Padahal akan lebih baik lagi semua tertera dengan jelas mulai dari fasilitas kesehatan yang digunakan dan kelasnya.

Meskipun, kualitas layananan yang diberikan juga memanfaatkan teknologi informasi yakni menggunakan website yang bisa diakses dari mana saja yakni www.utdpmipekanbaru.or.id. Kantor UTD PMI Kota Pekanbaru juga memberikan kesempatan kepada masyarakat dan keluarga pasien khususnya untuk berdiskusi atau konsultasi perihal permasalahan yang dihadapi.

Selama di Kantor UTD PMI Kota Pekanbaru, segala persyaratan administrasi dan lainnya disediakan kepada masyarakat. Baik itu berkas untuk melakukan donor darah, formulir pendafattaran, hingga konsumsi atau snack dan vitamin bagi pendonor. Semua kebutuhan layanan ini diberikan secara gratis, mudah dan murah didapatkan.

Seperti yang diutarakan oleh salah seorang keluarga pasien penerima donor darah, Ani Marlina, bahwa ia awalnya tidak paham dengan proses yang berjalan di Kantor UTD PMI Kota Pekanbaru, maka ia minta kepada petugas untuk diberikan pendampingan. Setelah dijalani ternyata urusan berjalan dengan transparan, mudah dan terbuka.

\section{Akuntabilitas}

Di dalam melakukan pelayanan, sebagai bentuk pertanggung yang dilakukan/ akuntabilitas moral adalah dengan melakukan melakukan pelayanan setiap hari kerja. Selama 24 jam yang dibagi ke dalam shif layanan pagi, siang dan malam tidak mengenal hari libur mengingat permintaan akan darah donor untuk tranfusi bisa datang kapan saja.

Untuk memenuhi kualitas mutu darah yang dihasilkan, menurut Sekretaris UTD PMI Kota Pekanbaru, Yayat Supriyatna, sudah melakukan QC (Quality Control) sebukan sekali. Pemeriksanaan yang dilakukan meliputi fisik, hematology dan kontaminasi bakteri.

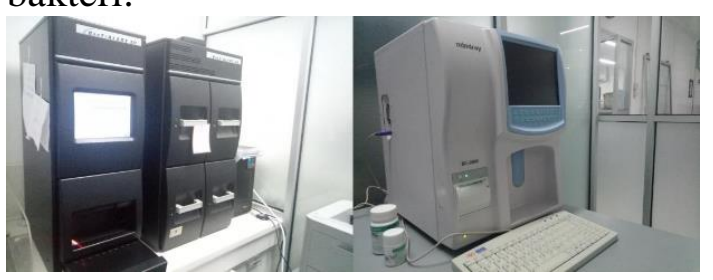

Gambar 2. Alat QC

Kemudian seluruh laporan kegiatan dilakukan setiap bulan sesuai degan format dari Peraturan Menteri Kesehatan Nomor 83 Tahun 2014. Laporan juga ditembuskan kepada Pengurus PMI Kota Pekanbaru, Dinas Kesehatan Kota Pekanbaru dan Dinas Kesehatan Provinsi Riau.

Begitupula dengan segala biaya yang ditimbulkan semuanya mengacu pada ketentuan yang berlaku baik peserta Badan Penyelenggara Jaminan Sosial (BPJS) maupun umum. Untuk peserta BPJS pembiayaan juga disesuikan dengan kelas peserta yakni I, II dan III. Ada yang semuanya ditanggung oleh BPJS ada juga yang tidak. Sedangkan untuk peserta umum, maka semua biaya ditanggung oleh pasien. 
Untuk urusan pembiayaan, Kantor UTD PMI Kota Pekanbaru menyediakan layanan/ ruang khusus/ loket keuangan dengan menempatkan petugas yang bertanggung jawab. Begitu pula sumber daya manusia yang ditempatkan senantiasa melaporkan kinerja kepada pimpinan melalui jalur dari suba bagian keuangan kepada sekretris kantor.

Selama ini segala kegiatan dapat dipertanggung jawab sesuai dengan ketentuan yang berlaku dan tidak ada menimbulkan penyimpangan. Artinya, segala kegiatan termasuk laporan keuangan, pengadaan peralatan dan perlengkapan sangat akuntabel. Berkaitan dengan biaya, pasien dikenakan biaya untuk pengganti pengolahan darah (BPPD) trombosit apaheresis, pemeriksaan darah rutin, uji saring dan uji silang.

Dalam hal pengawasan/ penilaian terhadap kualitas pelayanan darah (Blood Establisment) dan aspek Good Manufacturer Product-GMP/ Cara Pembuatan Obat yang Baik-CPOB untuk produk darah dilakukan melalui sertifikasi oleh institusi yang ditunjuk pemerintah. Institusi tersebut yaitu Badan Pengawas Obat Dan Makanan (BPOM) dan Direktorat Akreditasi Dan Mutu Kementerian Kesehatan.

\section{Kondisional}

Bagi Kantor UTD PMI Kota Pekanbaru, kondisional yang diberlakukan diantaranya dalam hal darah pengganti. Kantor UTD PMI Kota Pekanbaru tidak langsung meminta kepada keluarga pasien untuk mencari darah mengganti, darah pengganti diberlakukan kapan saja/ kondisional sesuai dengan ketersediaan pendonor, yang terpenting darah pengganti ada.

Secara teori, kondisional yang dimaksud adalah pelayanan yang sesuai dengan kondisi dan kemampuan pemberi dan penerima pelayanan. Namun tetap berpegang pada prinsip efisiensi dan efektivitas. Oleh karena itu apa yang dilakukan oleh Kantor UTD PMI Kota Pekanbaru sudah sesuai secara teori dan praktis. Pencadangan darah/ stock merupakan salah satu bentuk efektivitas yang dilakukan.

Dengan demikian darah tetap tersedia kapan dibutuhkan karena memiliki ruang penyimpanan khusus. Begitu pula ketika terjadi pendemi Corona Virus Disease Tahun 19 (Covid 19) sempat ada kekhawatiran terjadi kekurangan stok darah yang luar biasa hingga awal Mei 2020, ternyata tidak. Namun semua pihak diajak untuk mendonorkan darahnya karena sangat dibutuhkan oleh pasien rumah sakit baik negeri dan swasta. Berbagai unsur masyarakat terlibat dalam aksi gerakan donor darah seperti Tentara Nasional Indonesia/ TNI, mahasiswa dan masyarakat umum lainnya. Dalam satu bulan saja kebutuhan darah bisa mencapai 5.000-7.000 namun di bulan Ramadhan kaemarin menurun 4.000-5.000.

Dari segi waktu juga, pihak Kantor UTD PMI Kota Pekanbaru memberlakukan kondisional. Pendonor bisa donor kapan saja; pagi, siang, sore bahkan malam sesuai dengan kondisi fisik badan, kelapangan waktu dan lain sebagainya. Begitu pula dala hal pembiyaan dilaksanakan secara kondisional, artinya sesuai dengan fasilitas kesehatan yang didapatkan pasien. Ketika pasien mendapatkan fasilitas kesehatan gratis untuk semua kantong darah, maka tidak dipungut biaya. Bagi pasien yang fasilitas kesehatannya juga tidak penuh maka akan dikenakan biaya tambahan.

\section{Partisipatif}

Bentuk partisipatif yang diberlakukan oleh Kantor UTD PMI Kota Pekanbaru adalah dengan mengajak semua pihak untuk menjadi peserta aktif sebagai sukarelawan donor darah dan melakukan kerjasama dengan perusahaan atau instansi pemerintahan. Selain itu juga melakukan jemput bola dengan menyedikan mobil layanan donor darah. Hanya sampai dengan saat ini tidak semua pihak yang menjadi sukarelawan aktif mendonorkan darah, apalagi untuk saat ini ditengah pendemi virus corona ada kekhawatiran masyarakat 
untuk berurusan dengan kegiatan medis karena takut tertular.

Begitu pula dengan kerjasama dengan instansi pemerintah dan perusahaan swasta belum semua yang mau melaksanakan. Oleh karena itu maka pengambilan donor darah dilakukan baik dengan Kantor UTD PMI Kota Pekanbaru langsung maupun melalui jemput bola/ kegiatan-kegiatan sosial donor darah dan panitia donor darah.

Dengan semakin meningkatnya permintaan darah untuk transfusi maka Kantor UTD PMI Kota Pekanbaru menurut dr Dian IK Singgih selaku Kepala Bagian Pelayanan, dituntut untuk melaksanakan program kerja P2D2S (Program Pencarian dan Pelestarian Donor Darah Sukarela). Dengan program ini maka dar waktu ke waktu perolehan darah senantiasa mengalami peningkatan.

Kantor UTD PMI Kota Pekanbaru juga melaksanakan upaya jemput bola dengan melakukan pengumpulan darah yang dilaksanakan oleh tim khusus (Tim Mobile). Tim Mobile ini mendatangi tempat yang berpotensi menyumbangkan darah seperti pusat keramaian, lembaga pemerintah/ swasta, TNI/ Polri. Dari pendonor yang ada saat ini lebih dari $50 \%$ berada pada usia produktif yang diharapkan terus menjadi pendonor aktif. Sementara berdasarkan pekerjaan didapatkan hampir separuh pendonor adalah karyawan swasta sedangkan pendonor dari unsur Pegawai Negeri Sipil (PNS) hanya $7 \%$.

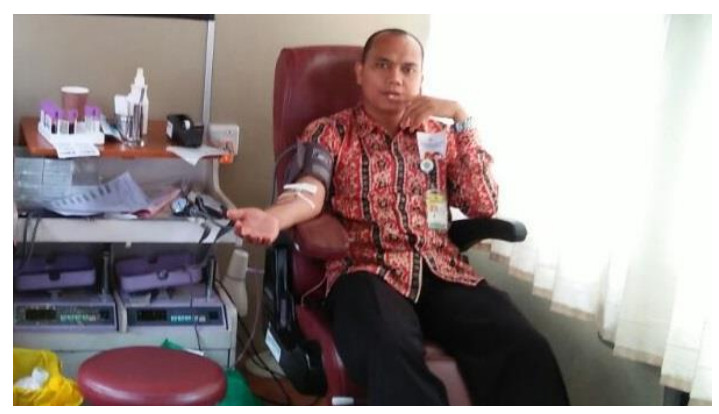

Gambar 3. Kegiatan Donor Darah

\section{Kesamaan Hak}

Secara teoritis, kesamaan hak yang dimaksud adalah pelayanan yang tidak melakukan diskriminasi dilihat dari apsek apapun khususnya suku, agama, ras, antar golongan, status sosial dan lainnya. Hal ini diwujudkan dengan pelayanan tanpa status tersebut oleh Kantor UTD PMI Kota Pekanbaru. Semua masyarakat diperbolehkan untuk mendonorkan darahnya dan diberikan pelayanan yang sama.

Bahkan kelompok-kelompok masyarakat tertentu memanfaatkan komunitasnya untuk melakukan gerakan sukarelawan donor darah seperti Ikatan Keluarga Jawa Riau/ IKJR yang ada di Pekanbaru. Di satu sisi keragaman tersebut memberikan potensi untuk gencar melakukan kegiatan kemanusian dengan donor darah.

Begitu pula dengan aparatur yang ada di Kantor UTD PMI Kota Pekanbaru serta masyarakat yang dilayani semua berasal dari berbagai unsur yang ada di masyarakat.Semuanya memiliki kesamaan hak tanpa dibatasi sesuai dengan aturan yang berlaku. Berdasarkan informasi masyarakat jumlah aparatur masih perlu ditingkatkan karena terkadang masih terjadi antrian dalam pemeriksanaan darah awal. Tentunya bagi masyarakat yang mudah jenuh akan mempengaruhi psikologi dalam pendonoran dan berpotensi gagal.

Hanya saja atau perlu juga diketahui ada pihak-pihak yang tidak disarankan untuk mendonorkan darahnya demi keamanan kesehatan. Yaitu orang - orang yang dengan penyakit tertentu seperti HIV/ AIDS, hepatitis, penyakit jantung, infeksi menular seks, penyakit paru dan kanker. Kemudian beberapa kelompok orang yang dianggap beresiko, tidak memenuhi syarat untuk menyumbankan darah untuk jangka waktu tertentu atau seumur hidup adalah laki-laki yang melakukan hubungan intim sesama lelaki/ gay/ homo, pekerja seks komersial dan pengguna obat-obatan terlarang. Hal ini terkesan diskriminatif namun perlu diketahui untuk mencegah/ menekan penyebaran penyakit berbahaya. 


\section{Keseimbangan Hak dan Kewajiban}

Kedua hal ini perlu dijaga. Hak adalah sesuatu yang kita terima sementara kewajiban adalah sesuatu yang harus kita lakukan. Tidak bisa meminta hak tapi kewajiban tidak dilakanakan. Kesimbangan hak dan kewajiban juga dipahami sebagai pelayanan yang mempertimbangkan aspek aspek keadilan antara pemberi dan penerima pelayanan publik.

Masyarakat yang berurusan di Kantor UTD PMI Kota Pekanbaru berhak mengetahui prosedur pelayanan permintaan darah, biaya yang ditanggung dan fasilitas lainnya. Sementara kewajiban yang harus dipenuhi oleh masyarakat adalah mengisi dan memberikan data yang benar dan akurat, membayar biaya sesuai ketentuan yang berlaku.

Kenapa harus memberikan data yang benar? Karena, pada saat kegiatan donor darah juga terdapat pendonor yang gagal donor dikarenakan pusing, rasa takut, hemoglobin rendah dan lainnya. Kondisi ini menyebabkan kerugian, dimana biaya telah terpakai untuk kantong darah, reagen pemeriksaan dan lain sebagainya. Dari semua darah donor harus dilakukan uji saring untuk mencegah penularan penyakit, infeksi menular lewat transfusi darah (IMLTD) yang harus disesuaikan dengan standar.

Kantor UTD PMI Kota Pekanbaru untuk uji tersebut menggunakan metode CMIA (Chemiluminescent Microparticle Immunoassay) menggunakan mesin Architect dan Cobas dan NAT (Nucleid Acid Testing) menggunakan mesin Procleix Panther. Hasilnya, beberapa tahun terakhir memang terjadi pendonor yang ditemukan positif, sehingga donor darah harus dimusnahkan.

\section{SIMPULAN}

Dari penelitian yang telah dilakukan diperoleh kesimpulan sebagai berikut:

1. Kualitas pelayanan di Kantor UTD PMI Kota Pekanbaru sudah berjalan sesuai dengan prinsip - prinsip pelayanan yang baik secara teori dan peraturan Menteri Kesehatan RI

2. Hal yang perlu diperhatikan dalam kualitas pelayanan adalah jumlah petugas medis yang melakukan pengecekan darah awal dan informasi tentang standar biaya.

\section{SARAN}

Oleh karena itu bebeberapa hal yang perlu disarankan untuk peningkatan kualitas pelayanan adalah:

3. Peningkatkan jumlah aparatur atau petugas medis dalam pemeriksaan darah awal sehingga masyarakat cepat ditangani.

4. Memberikan informasi lapangan kepada masyarakat sehingga tidak perlu lagi bertanya kepada petugas atau aparatur Kantor UTD PMI Kota Pekanbaru.

\section{DAFTAR PUSTAKA}

Abu Ahmadi dan Noor Salimi, 2008, DasarDasar Pendidikan Agama Islam, Bumi Aksara, Jakarta.

Agus Dkk, 2012, Modul Monitoring Penegakan Hukum, ICW, Jakarta.

Anggara Sahya. 2012. Perbandingan Administrasi Negara. CV Pustaka Setia, Bandung.

Beddy Iriawan, 2012. Sistem Politik Indonesia, Rajawali Pers, Jakarta

Chrisyanti, 2011, Pengantar Ilmu Administrasi, Prestasi Pustaka Publisher, Jakarta.

Danang Sunyoto dan Burhanuddin, 2011, Perilaku Organisasional, CAPS, Yogyakarta.

Deddy Mulyadi, 2015. Studi Kebijakan Publik Dan Pelayanan Publik, Alfabeta, Bandung.

Hamdi Muchlis, 2014, Kebijakan Publik, Ghalia Indoesia, Bogor.

Kaelan, 2010, Pendidikan Pancasila, Paradigma, Yogyakarta. 
Lijan Sipoltak, dkk, 2014, Reformasi Pelayanan Publik, Bumi Aksara, Jakarta.

MPR RI, 2012, Ketetapan MPR RI Nomor I/ MPR/ 2003 Tentang Peninjauan Kembali Materi dan Status Hukum Ketetapan MPR Sementara dan Ketetapan MPR RI Tahun 1960 2002, Sekretariat Jenderal MPR RI, Jakarta

Padmo Wahjono dan Nazaruddin Syamsuddin, 2009, Pengantar Ilmu Politik, PT Raja Grafindo Persada, Jakarta.

Riant Nugroho dan Randy Wrihatnolo, 2011, Manajemen Perencanaan Pembangunan, Kompas Gramedia, Jakarta.

Ridwan HR, 2010, Hukum Administrasi Negara, PT Raja Grafindo Persada, Jakarta.

Siti Fajar dan Tri Heru, 2013, Manajemen Sumber Daya Manusia, UPP STIM YKPN, Yogyakarta.

Subhan Sofhian dan Asep Sahid, 2011, Pendidikan Kewarganegaraan, Fokus Media, Bandung.

Wibowo, 2010, Budaya Organisasi, Rajawali Pres, Jakarta.

Yusuf Muri, 2014, Metode Penelitian; Kuantitatif Kualitatif dan Penelitian Gabungan, Prenada Media Grup, Jakarta. 